Revue bibliographique pour le domaine irano-aryen

\title{
Małgorzata Abbasy. Modernizacja w cieniu Allaha: współczesny Iran [Modernisation à l'ombre d'Allah : Iran contemporain]
}

\section{Rédaction}

\section{(2) OpenEdition}

\section{Journals}

Édition électronique

URL : https://journals.openedition.org/abstractairanica/51897

DOI : 10.4000/abstractairanica.51897

ISSN : 1961-960X

Éditeur :

CNRS (UMR 7528 Mondes iraniens et indiens), Éditions de l'IFRI

Référence électronique

Rédaction, « Małgorzata Abbasy. Modernizacja w cieniu Allaha: współczesny Iran [Modernisation à I'ombre d'Allah : Iran contemporain] », Abstracta Iranica [En ligne], Volume 42-43 | 2021, document 2, mis en ligne le 30 décembre 2020, consulté le 12 décembre 2022. URL : http://

journals.openedition.org/abstractairanica/51897 ; DOI : https://doi.org/10.4000/abstractairanica. 51897

Ce document a été généré automatiquement le 12 décembre 2022.

Tous droits réservés 


\section{Małgorzata Abbasy. Modernizacja w cieniu Allaha: wspótczesny Iran [Modernisation à l'ombre d'Allah : Iran contemporain]}

Rédaction

\section{RÉFÉRENCE}

Małgorzata Abbasy. Modernizacja w cieniu Allaha: współczesny Iran [Modernisation à l'ombre d'Allah : Iran contemporain]. Kraków [Cracovie] : Wydawnictwo Uniwersytetu Jagiellońskiego, 2019, 141p., bibliographie, index. ISBN : 978-83-233-4658-6 ; ISBN : 978-83-233-9998-8 (e-book)

1 Le système politique de la République islamique d'Iran est ici abordé et analysé en termes de stratégie culturelle d'un genre particulier. L'auteur postule que son développement et sa transformation, y compris les changements effectués en vue de sa modernisation en réaction aux défis posés par le monde occidental, sont entrés actuellement dans une phase de crise aiguë. Cette crise est conditionnée par une tension extrême entre le désir de préserver le status quo et la nécessité objective du changement. Dans l'histoire de l'Iran, les crises précédentes ont abouti à deux révolutions : constitutionnaliste (1905-1911) et islamique (1979). La révolution qui viendra en réaction à la crise actuelle dévoilera la nouvelle réponse de l'Iran face au défi de la modernisation, lancé par l'Occident au début du XIX' ${ }^{\mathrm{e}}$ siècle.

2 Après une brève introduction (p. 7-13), l'ouvrage développe ses analyses en six chapitres, abordant les problématiques suivantes: 1 . Théorie et méthodologie des recherches (Teoria i metodologia badań, p. 15-35), 2. «Ombre d'Allah » et ses gardiens : le clergé chiite ("Cień Allaha" i jego strażnicy: duchowieństwo szyickie, p. 37-57), 3. L'espace symbolique de la nation iranienne à la lumière de la matrice de l'islam chiite 
(Symboliczna przestrzeń narodu irańskiego w świetle matrycy szyickiego islamu, p. 59-72), 4. Les mécanismes de contrôle de la société: les dirigeants versus les dirigés (Mechanizmy sterowania społeczeństwem: rzĄdzĄcy a rzĄdzeni, p.73-95), 5. La société iranienne comme miroir de la condition de l'élite dirigeante (Irańskie społeczeństwo zwierciadłem kondycji elity rzĄdzĄcej, p. 97-117), 6. Ressources énergétiques comme un élément de la stratégie culturelle (Surowce energetyczne jako czĘść strategii kulturowej, p. 119-126). Quelques pages de conclusion (p. 127-131) closent l'ouvrage.

\section{AUTEURS}

\section{RÉDACTION}

Direction et secrétariat d'Abstracta Iranica 